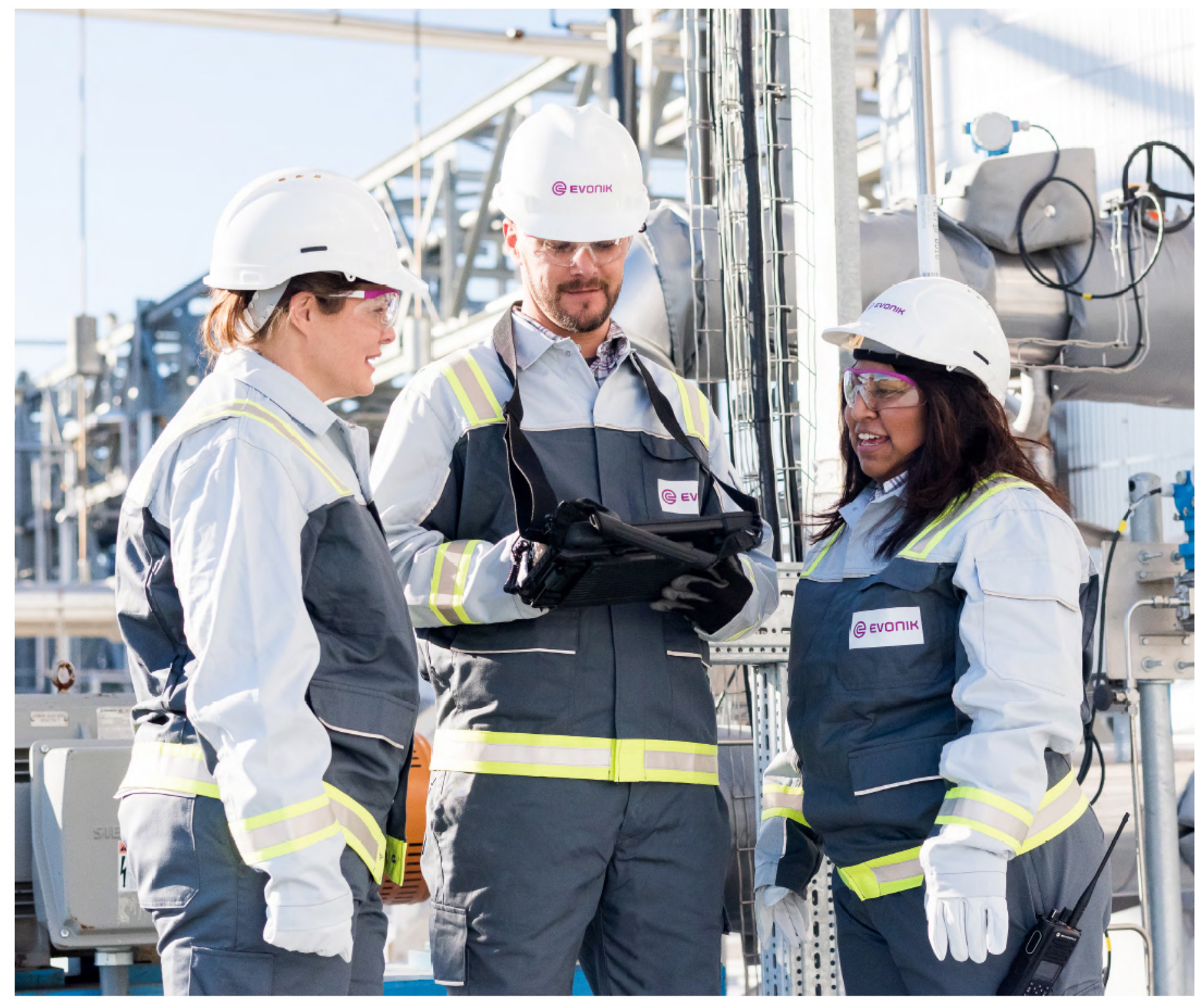

Process engineering on a new level? It takes \#HumanChemistry
Make your curiosity and talent as an engineer matter to the world with a specialty chemicals leader.

Together, we combine cutting-edge science with engineering expertise to create solutions that answer real-world problems. Find out how our approach to technology creates more opportunities for growth, and see what chemistry can do for you at:

\section{evonik.com/career}

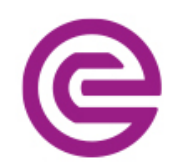

EVDחIK Leading Beyond Chemistry 


\title{
Molecular genetic analysis of neural stem cells after space flight and simulated microgravity on earth
}

\author{
Yilin Han $^{1}$ | Lukas Zeger $^{1}$ | Rekha Tripathi ${ }^{2}$ | Marcel Egli ${ }^{3}$ | Fabian Ille ${ }^{3}$ | \\ Christian Lockowandt $^{4}$ | Gunnar Florin ${ }^{4}$ | Edvin Atic ${ }^{5}$ | Itedale N. Redwan ${ }^{5}$ | \\ Robert Fredriksson $^{2}$ | Elena N. Kozlova ${ }^{1}$
}

\author{
${ }^{1}$ Department of Neuroscience, Regenerative \\ Neurobiology, Uppsala University, Uppsala, \\ Sweden \\ ${ }^{2}$ Department of Pharmaceutical Bioscience, \\ Molecular Pharmacology, Uppsala University, \\ Uppsala, Sweden \\ ${ }^{3}$ Luzerne School of Engineering and \\ Architecture, Institute of Medical Engineering \\ (IMT), Luzerne, Switzerland \\ ${ }^{4}$ Swedish Space Corporation, Science Service \\ Division, Solna, Sweden \\ ${ }^{5}$ CELLINK AB, Gothenburg, Sweden

\section{Correspondence} \\ Elena N. Kozlova, Department of \\ Neuroscience, Biomedical Center, Box 593, \\ 75124 Uppsala, Sweden. \\ Email: elena.kozlova@neuro.uu.se
}

\begin{abstract}
Understanding how stem cells adapt to space flight conditions is fundamental for human space missions and extraterrestrial settlement. We analyzed gene expression in boundary cap neural crest stem cells (BCs), which are attractive for regenerative medicine by their ability to promote proliferation and survival of cocultured and co-implanted cells. BCs were launched to space (space exposed cells) (SEC), onboard sounding rocket MASER 14 as free-floating neurospheres or in a bioprinted scaffold. For comparison, BCs were placed in a random positioning machine (RPM) to simulate microgravity on earth (RPM cells) or were cultured under control conditions in the laboratory. Using next-generation RNA sequencing and data post-processing, we discovered that SEC upregulated genes related to proliferation and survival, whereas RPM cells upregulated genes associated with differentiation and inflammation. Thus, (i) space flight provides unique conditions with distinctly different effects on the properties of BC compared to earth controls, and (ii) the space flight exposure induces postflight properties that reinforce the utility of $\mathrm{BC}$ for regenerative medicine and tissue engineering.
\end{abstract}

\section{KEYWORDS}

bioprinting, gene expression, gravity, neural stem cell, regenerative medicine

\section{1 | INTRODUCTION}

Humans embarking on space missions are subjected to pronounced physiological stress, mainly from the exposure to hyper- and microgravity resulting in a slowing of the cardiovascular system, redistribution of body fluids, weakening of the immune system, muscle atrophy, osteopenia, and loss of body mass (Demontis et al., 2017).
Space flight conditions have also been shown to alter brain structure and functions with more severe effects after long-term rather than short-term space missions.

Stem cells are fundamental for the development and growth of the organism, for renewal of cells with a limited lifespan, as well as for tissue regeneration and repair after injury or disease. Stem cells have also emerged as an attractive source for cell replacement and

Rekha Tripathi and Marcel Egli contributed equally to this study.

This is an open access article under the terms of the Creative Commons Attribution-NonCommercial-NoDerivs License, which permits use and distribution in any medium, provided the original work is properly cited, the use is non-commercial and no modifications or adaptations are made.

(c) 2021 The Authors. Biotechnology and Bioengineering Published by Wiley Periodicals LLC 
trophic support, as well as for disease-modifying purposes. Understanding how stem cells adapt to space conditions is thus important for protecting for example bone forming cells (Ozcivici et al., 2010) and hematopoietic stem cells and their progeny (Cao et al., 2019) in space missions (reviewed in Grimm et al., 2020; Zhang et al., 2015), but also for translational regenerative medicine (Grimm et al., 2018; Imura et al., 2018).

Microgravity is a major physical challenge during space flight and in an extraterrestrial environment. The effect of microgravity has been studied previously on various types of stem cells on the international space station, or on earth, using devices designed to simulate microgravity (e.g., random positioning machine [RPM] or clinostat). These studies show that the cellularas effects of microgravity may be beneficial or unfavorable (reviewed in Zhang et al., 2015). Thus, microgravity was shown to promote neuronal differentiation of mesenchymal stem cells (MSC; Chen et al., 2011) and adipose stem cells (Graziano et al., 2018; Zarrinpour et al., 2017), and to promote cardiomyocyte development (Baio et al., 2018; Camberos et al., 2019; Li et al., 2019). On the other hand, under the influence of microgravity, bone marrow-derived mesenchymal stem cells failed to undergo neuronal differentiation (Yuge et al., 2011), maturation of oligodendrocyte precursor cells was delayed (Espinosa-Jeffrey et al., 2013), differentiation of embryonic stem cells were reduced (Blaber et al., 2015; Shinde et al., 2016; Zhang et al., 2015), osteogenic differentiation (Chen et al., 2015, 2016), and migration of MSC (Mao et al., 2016) were inhibited, beating rate in human induced pluripotent (iPC)-derived cardiomyocytes increased (Acharya et al., 2018), and autonomic neuronal differentiation of neural crest stem cells impaired (Hatzistergos et al., 2018).

Although simulated microgravity on earth shares the principles of microgravity in space, stem cells may display distinctly different responses in space compared to microgravity simulated on earth (Zhang et al., 2015). However, the environmental conditions to reach space and thus exposing cells to microgravity are different than generating a simulated microgravity environment for sample cells on the ground. Although a state of hypergravity precedes space microgravity, the simulated microgravity requires at least $48 \mathrm{~h}$ in RPM to achieve comparable effect. But regardless of the method used for inducing this weightlessness stress to stem cells on earth, they may in fact respond in a different way compared to space exposed cells (SEC) in an altered gravitational setting. It is therefore challenging and important to determine possible undesirable effects caused by microgravity, which cannot be determined in earth experiments, and also to identify possible novel features of potential beneficial effects with translational implications. Here, we explore how space conditions, compared to RPM conditions applied on earth, affect gene expression in boundary cap neural crest stem cells (BCs).

BCs are a transient neural crest-derived group of cells that selfrenew, show multipotency in culture (Aldskogius et al., 2009; Hjerling-Leffler et al., 2005; Maro et al., 2004), and are able to differentiate into neurons and glia in vitro and after transplantation to the peripheral (Aquino et al., 2006) or central nervous system (CNS) (Radomska \& Topilko, 2017; Trolle et al., 2014; Zujovic et al.,, 2011) in vivo. BCs have emerged as a highly attractive resource for regenerative medicine due to their remarkable, beneficial effects on insulin-producing $\beta$ cells (Grapensparr et al., 2015; Grouwels et al., 2012; Lau et al., 2015; Ngamjariyawat et al., 2012; Olerud et al., 2009), and endangered motor neurons (Aggarwal et al., 2017; Leyton-Jaimes et al., 2020; Schizas et al., 2018). At the same time, $\mathrm{BC}$-derived astrocytes show extreme resistance to challenges such as oxidative stress (Aggarwal et al., 2017).

BCs were launched into space either as free-floating neurospheres or placed in a bioprinted scaffold. For comparison, BCs were subjected to space flight-mimicking condition, or RPM conditions (microgravity cells), or were cultured without physical challenges under control conditions in the laboratory. We show striking differences between SEC and microgravity cells, with SEC upregulating genes involved in cell proliferation and survival, whereas microgravity cells upregulated genes involved in differentiation and inflammation.

\section{2 | MATERIALS AND METHODS}

\subsection{Culture of boundary cap neural crest stem cells (BC)}

BCs were isolated from a 11.5 day embryo of transgenic mice harboring red fluorescent protein (RFP) under the universal actin promoter (Vintersten et al., 2004) according to previously published protocols (Aldskogius et al., 2009; Hjerling-Leffler et al., 2005). Briefly, the spinal cord was exposed and dorsal root ganglia, including their attachment with the spinal cord, gently separated and mechano-enzymatically dissociated using collagenase/dispase $(1 \mathrm{mg} / \mathrm{ml})$ and DNase $(0.5 \mathrm{mg} / \mathrm{ml})$ for $30 \mathrm{~min}$ at room temperature. Cells were plated at $0.5-1 \times 10^{5}$ cells $/ \mathrm{cm}^{2}$ in $\mathrm{N}_{2}$ medium containing B27 (Gibco) as well as EGF and bFGF (R\&D Systems; $20 \mathrm{ng} / \mathrm{ml}$, respectively). After $12 \mathrm{~h}$ of culture, cells that had not adhered were removed together with half of the medium, and a fresh medium was added. The medium was changed every second day, and neurospheres could be observed after about 2 weeks of culture. After being placed in a differentiation medium, dissociated BC differentiated into either cells positive for glial fibrillary acidic protein (GFAP) or for the neuronal marker $\beta$-tubulin. For the experiments, 30 neurospheres were placed in each Eppendorf vial, corresponding to ca $1.4 \times 10^{4}$ cells per $\mathrm{ml}$.

\section{2 | Preparation of bioprinted BC for space flight and earth experiments}

As we did not know whether free-floating cells would survive space flight, we prepared, in addition, 3D bioprinted specimens with BC embedded in a bioscaffold to provide protection from the physical forces during space voyage. For $3 \mathrm{D}$ printing, $\mathrm{BC}$ s were delivered to CELLINK AB (www.cellink.com). Spheroid samples were centrifuged 
and the supernatant discarded. The remaining pellet was mixed in CEIIINK Bioink (CELLINK AB, IK1020000303) and printed with crosslinking by immersing the constructs in a $50 \mathrm{mM}$ solution of $\mathrm{CaCl}_{2}$ for 2 min. The printed scaffolds with $\mathrm{BCs}$ were placed in Eppendorf tubes as three separate droplets.

\subsection{Overview of cultures for space flight and earth experiments}

We prepared three samples for each space and earth control experiments. BCs were cultured either as free floating neurospheres or placed in 3D-printed scaffold (CellINK). Free-floating and 3D printed BC samples were sent to space (Figure 1, first and second panel). As samples for space experiment were outside of the $37^{\circ} \mathrm{CO}_{2}$ incubator for 2 weeks, we prepared several controls for the postflight analyses to account for detrimental non-space-related effects. Therefore, on the earth we prepared BC in 3D printed condition (Figure 1, panel 3), $\mathrm{BC}$ on the bench outside of the $37^{\circ} \mathrm{CO}_{2}$ incubator for 2 weeks (Figure 1, panel 6), BC in thermostat in normal culture conditions (Figure 1, panel 7), $\mathrm{BC}$ outside of the $37^{\circ} \mathrm{CO}_{2}$ incubator for 2 weeks and subjected to mimicking space experiment (12 min flight condition) (Figure 1, panel 5), BC in RPM (earth simulated microgravity condition on earth in RPM) (Figure 1, panel 4).

\section{4 | Space flight experiments}

$B C$ in CELLINK and as free-floating neurospheres were collected in Eppendorf tubes, which were placed in a Styrofoam box and delivered to the launch site at Esrange-Kiruna (https://www. sscspace.com/ssc-worldwide/esrange-space-center/). The box was placed in the bottom of the rocket MASER 14 (https://www. sscspace.com/maser-14/) 1 week before take-off. In parallel, BCs were placed on a bench in the lab in Eppendorf tubes and the medium was not changed during the whole experimental time for 2 weeks in all earth control cultures (Figure 1, panels 4-6). After the space voyage, the cells were returned to the laboratory and placed in fresh medium to the thermostat to generate new neurospheres and RNA was collected when sufficient cell mass was reached in each sample. As an additional control, RNA was collected from the cells cultured under normal conditions in the $\mathrm{CO}_{2}$ incubator.

\subsection{Simulated microgravity and altered gravity experiments}

In the Institute of Medical Engineering, IMT, Switzerland, an additional gravity experiment was conducted, which reconstructed the 12 min space condition by using a centrifuge for hypergravity and the RPM for microgravity conditions. The hyperfuge (Diport AG) centrifuge was set at $4 \mathrm{~g}$, with a speed of $154 \mathrm{rpm}$ and a $14^{\circ}$ angle of inclination. For simulated microgravity was used the RPM, consisting of a gimbal-mounted platform, which allowed to rotate samples continuously around two perpendicular axes. The two axes were each driven by electrical engines, which operated independently from each other. Both engines were controlled by custom-made software [Wuest et al., 2014) running on a laptop. The platform was rotated with constant velocity, set to $60 \%$ s, but the rotation direction was inverted at random time points. The transition from forward to backward took place at $10 \% \mathrm{~s}^{2}$. The experiments were performed with cells that had been out of the incubator for the same time as those cells were sent into space (14 days).

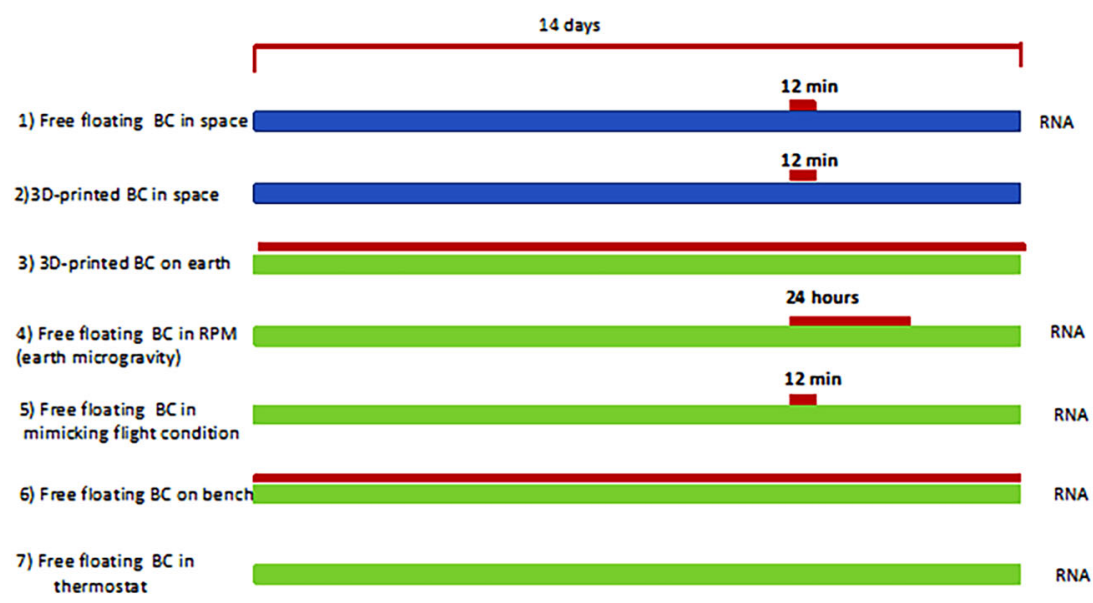

FIGURE 1 Overview of boundary cap neural crest stem cell (BC) samples in space and on earth. BC have been cultured as free-floating neurospheres (panels 1, 4,5,6), or have been printed in 3D scaffolds (panels 2 and 3 ) outside of the $37^{\circ} \mathrm{CO}_{2}$ incubator for 14 days. $\mathrm{BCs}$ were in space for $12 \mathrm{~min}$ with $6 \mathrm{~min}$ microgravity (panel 1). To mimic space conditions, BC have been subjected to 6 min hypergravity and 6 min simulated microgravity on earth (panel 5). BC also have been placed to RPM for $24 \mathrm{~h}$ to achieve microgravity-like conditions on earth (panel 4). For comparison cells were cultured outside of the $37^{\circ} \mathrm{CO}_{2}$ incubator on bench (position 6) or in thermostat (panel 7). From all cultures with free floating neruospheres, RNA was collected for genetic analysis 


\section{6 | Postflight culture, survival, and viability assay}

The SEC from free-floating cultures were delivered to the laboratory and live images were taken daily during the first week of culture, using inverted fluorescence microscopy to identify RFP expressing BC. The BC from all conditions were cultured for one to four weeks before they were collected for RNA collection. The rest of the cells was frozen for further experiments. The cultures were continuously evaluated with regard to overall BC survival to ensure that a sufficient amount of cells would be available for subsequent RNA analyses. For the same purpose, free-floating specimens were not taken for detailed cell counts or viability assessment.

3D printed specimens (Figure 1, panels 2, 3) were sent to CELLINK $A B$ immediately after landing and examined the next day for BC viability, using labeling protocols based on Calcein AM (live cells; Invitrogen eBioscience, product number 15560597) and propidium iodide (dead cells; Sigma-Aldrich, product number 81845-25MG).

\section{7 | Library preparation and RNA sequencing}

The libraries were prepared for sequencing on the Ion Chef System and sequenced on the Ion S5 XL on 540 chips using IonCode adapters. Sequencing libraries for 16 individual samples were prepared from 180 to $280 \mathrm{ng}$ total RNA using the lon AmpliSeq $^{\text {TM }}$ Transcriptome Mouse Gene Expression Kit (Cat. Nos. A36553, A36554, and A36555; Thermo Fischer Scientific) according to the manufacturer's protocol. Sequencing was then performed on lon S5 XL on 540 chips machine by the SNP\&SEQ Technology Platform in Uppsala. The data is available in EBI Array Express Repository with accession number E-MTAB-10543 (https://www.ebi.ac.uk/fg/annotare/edit/12785/\#DESIGN: SAMPLES).

\section{8 | RNA extraction and next-generation RNA sequencing}

RNA analyses were made from BC neurospheres derived from free-floating SEC and corresponding earth controls. Cells were grown in stem cell medium for one to four weeks after space voyage in the same culture conditions as described above before they were frozen for future experiments. RNA was extracted 2 weeks after the first split in every analysed group using an RNAEasy Plus Micro kit (Qiagen), according to the manufacturer's instructions. Concentrations were measured using an ND-1000 spectrophotometer (NanoDrop Technologies) and subsequently, RNA integrity was controlled by using an Agilent 2100 Bioanalyzer. Ten ng of RNA was used for each sample.

\section{9 | Data post-processing and analysis}

Free-floating BC from space and earth controls showed large diversity in cell proliferation. However SEC demonstrated a remarkable rate of proliferation (around 12 times greater than earth control on bench), the cells subjected to the space mimicking experiment demonstrated extremely low proliferation capacity compare to all other groups (Figure 1, panel 5). As cells in space and in RPM conditions had been outside of the $37^{\circ} \mathrm{CO}_{2}$ incubator for 2 weeks, we had to exclude these "outside-ofincubator" effects from our analysis to see only effects from space and simulated microgravity conditions. We used several controls on the ground, including cells kept in the thermostat and cells kept on the bench with the same conditions as the cells in the space (no medium change, no gas access). We then excluded from genetic analysis all genes which were differentially regulated between these two groups, as we consider them as genes, which were affected by "out of $37^{\circ} \mathrm{CO}_{2}$ thermostat" conditions (Figure 1, panel 6, 7). The raw data was converted to the number of reads per transcript using an ampliSeqRNA plugin (Illumina) for the Torrent Suite Software (Illumina). These values were normalized by dividing the read number for each gene for each sample by the total number of reads for that gene. From these normalized gene expressions, a gene of interest list was created. First, all genes that were at least two-fold changed between cells outside the incubator and control cells, were removed because these were considered affected by the change in the environment between these groups and could be possible confounders, as described above. The remaining genes that were at least two-fold changed between RPM cells and SEC were included in the gene of interest list, which was used for subsequent analysis.

DAVID (Huang da et al., 2008, 2009) was used to identify functional clusters of enriched genes from the gene of interest list. The DAVID analysis was run using default settings. The same gene of interest list as used for the DAVID analysis was used for Reactome pathway analysis (Fabregat et al., 2018; Jassal et al., 2020), which was conducted with default settings.

Ingenuity pathway analysis (IPA) was performed by setting Gene only, specific cell selection in Cell-Neurons, Stem Cell, Brain-Cerebral cortex, and CNS cell lines. The data set used was the gene of interest list obtained from the data post-processing step. Canonical pathways and molecular functions were enriched to cell and stem cell differentiation, adhesion, and proliferation pathways.

\section{3 | RESULTS}

\subsection{Space flight cultures show increased survival and proliferation}

After $\mathrm{BC}$ return from the space, they were placed in a proliferation stem cell medium (Figure 2). In this medium BC typically grow as neurospheres (Figure 2b), but over the following two days, we detected strongly adhering SEC (Figure 2a), occupying the bottom of the wells (Figure 2a,c). On day three, SEC cultures displayed an exceptional amount of spheres (Figure 2d), compared to BC cultured on 
(a)

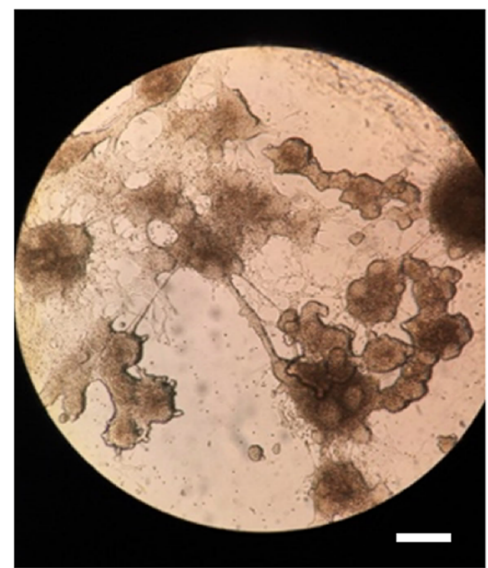

(b)

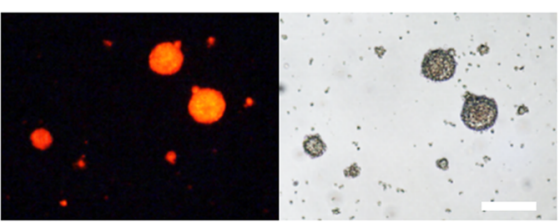

(c)

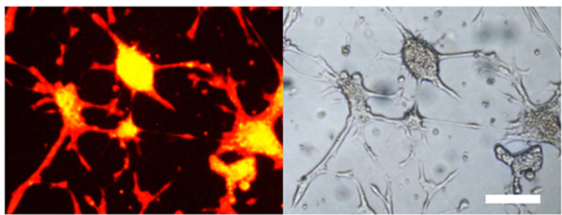

(d)

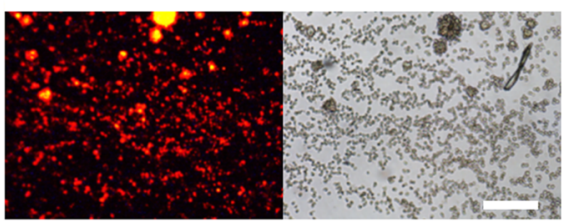

FIGURE 2 Overview of space (a,c,d) and earth (b) boundary cap neural crest stem cell (BC) cultures at Day $0(\mathrm{a}), 2$ (b,c) and Day 3 (d). The cells were cultured in proliferation stem cell medium. Scale bar $=100 \mu \mathrm{m}$

the ground (Figure 2b). The spheres had to be split 12 times faster in SEC cultures than in the other culture groups. Three months after the Space voyage we still detected increased proliferation in SEC. The SEC neurospheres were collected, split to single cells in parallel with control specimens, and evaluated for cell renewal. We found a significantly higher rate of proliferation in SEC compare to ground BC (Figure 3a,b).

BC placed in CELLINK Bioink scaffold survived space conditions markedly better than earth scaffold control cells, as shown with viability test $(p<.005$; Figure $3 c)$

\section{2 | Space flight and earth microgravity result in different patterns of gene expression}

We created a gene of interest list with those genes that were uniquely, at least two-fold, differentially expressed between SEC and RPM cells, by removing genes that showed altered expression as a result of maintaining the cells outside the incubator. We applied this gene of interest list for the Gene ontology analysis using DAVID and identified three functional groups that were highly enriched, namely "Adhesion," "Proliferation" and "Differentiation." These genes are shown in Table 1. We also created a similar list of genes up- or downregulated when comparing SEC with cells out of the $37^{\circ} \mathrm{CO}_{2}$ incubator (Table 2).

All genes which were different between the outside incubator control and normal incubator control were removed from the analysis to eliminate the effect of abnormal, outside incubator conditions.

\subsection{Space flight and RPM exposure resulted in markedly different pathway activation}

Genes associated with proliferation, adhesion, and differentiation showed significant differences between the space and RPM group. The Reactome Pathway Database revealed that SEC, unlike the RPM group, did not upregulate genes involved in programmed cell death and inflammation (immune system). In contrast, only SEC showed upregulation of genes associated with cell-cell communication and show multiple involvements in different neuronal pathways. These data show that BC subjected to space conditions acquire new properties, which might benefit their survival as well as their potential to support cocultured, coprinted, and cotransplanted cells.

\subsection{Ingenuity pathway analysis (IPA)}

We next applied the IPA software to the list of all genes which showed at least a twofold change. Comparative gene expression ratio between groups such as SEC versus space-mimicking cells, SEC versus outside incubator cells, outside incubator versus normal culture conditions, SEC versus RPM (simulated microgravity) cells, subjected to IPA software were specifically centered on stem cells type.

We found that the SEC have the highest activation of genes associated with cell proliferation and survival when compared to cells cultured outside the incubator (bench cells) (Figure 4a,b). This was most prominent when summarizing all genes from that signaling pathway as displayed in the top row of Figure 4a. Similarly, the cell survival pathway was highly activated in SEC when compared to control cells (Figure 4b). After performing top upstream regulator analysis, we identified TP73 as the most strongly predicted upstream regulator (Figure $4 c$ ) in the data set and six genes indicated inhibition of tumor protein TP73, a transcription regulator known to be involved in cellular responses to stress, and in development.

We next focused on possible pathways involved in cell viability. IPA predicted increased cell viability in SEC compared to other groups, as evidenced by the upregulation of several survivalassociated genes. Furthermore, genes regulating additional supportive cellular functions were upregulated, such as differentiation of 
(a)

\section{VBC}

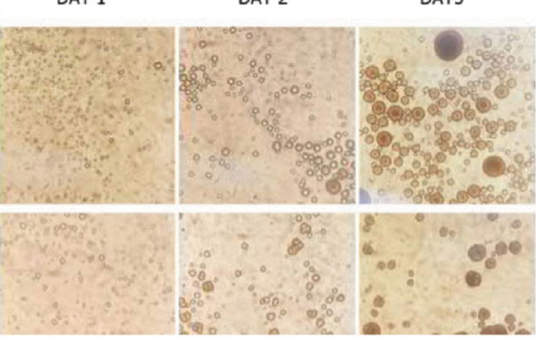

NBC (b)

SPACE

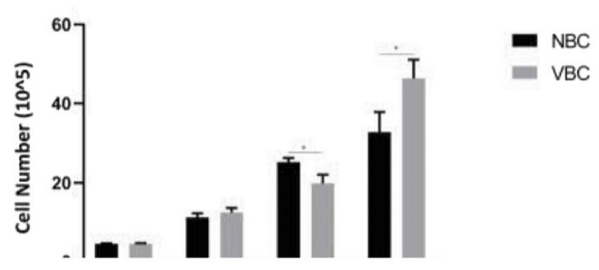

(c)

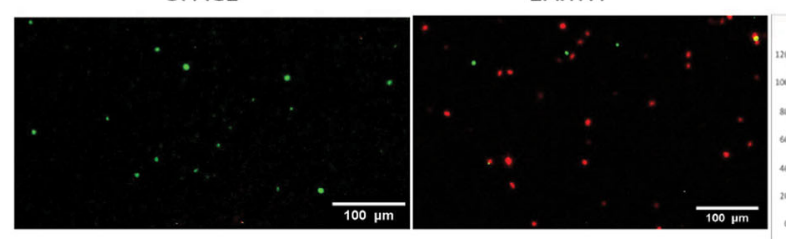

EARTH

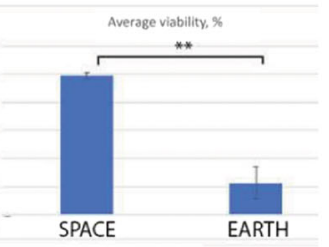

FIGURE 3 Overview of space (SEC) and earth bNCSC (BC) cultures at day 0,1,2,3. Neurospheres with increasing diameters are seen from Day 1 to Day 3 in both types of cultures (a), and with significantly greater $(p<.05)$ growth in SEC culture (b). The graph represents mean cell number in Space and Earth cultures 1, 2, and 3 days after the cells have been in culture with an initial equal number of cells. Viability data for surviving cells (calcein, green) and dead cells (propidium iodide, red) in space (left) and on earth (right). Separated BC, equally distributed inside the CELLINK Bioink scaffolds were counted after space flight (left panel) and in earth controls (right panel). The survival of BC in space samples $(n=3)$ was significantly greater $(p<.01$; Student's $t$ test) than in earth samples $(n=6)$ (right graph). A higher proportion of viable cells indicates increased viability and/or increased proliferation capacity of the pace flown cells

neuronal precursors, the survival of neural crest cells, as well as migration, activation, and development of embryonic stem cells (not shown).

Among all groups in SEC, the senescence pathway was predicted downregulated, which is supported by genes involved and affected in the pathway (Figure 5). Top network analysis was focused on genes involved in cellular development, growth, and proliferation of the nervous system in SEC. Genes involved showed increased cell viability of embryonic cells in SEC. Genes that are also involved in the differentiation of neuronal precursors, activation of embryonic stem cells, migration of embryonic cells, and survival of neural crest cells were also upregulated. Comparative analysis of all different groups showed the senescence pathway as one of the top canonical pathways which were indicated as inhibited in SEC as well as in RPM cells. In conclusion, both RPM cells and SEC show reduced stem cell senescence, which protects them from the natural cell ageing process, a process that affects the capacity for stem cell renewal. Genes involved in proliferation and survival are compiled in Table 3, including fold change and if the gene is up- or downregulated.

\section{4 | DISCUSSION}

We show that BC after being exposed to a sounding rocket flight that includes a period of real microgravity conditions displayed a remarkable survival, and improved viability compared to cells exposed to a simulated gravity environment on earth. BC viability was quantitatively assessed in 3D bioprinted, rather than in free-floating specimens, to reserve the latter material for gene expression analyses. Given our observation that free-floating SEC generate new neurospheres at a rate much greater than earth control specimens, the increased viability of $3 \mathrm{D}$ bioprinted SEC is most likely the result of a markedly elevated $\mathrm{BC}$ renewal.

These space flight-induced cellular changes were associated with significant differences in the activation of pathways for genes involved in proliferation, differentiation, and cell adhesion, indicating that BC successfully adapt to the challenging conditions of space flight and even acquire novel properties of benefit for cell function. In a short term perspective, these responses are in line with the impact of physical stress, which makes cells reorganize their cytoskeleton, restructure actin and cadherin complexes and flatten nuclear pores (Elosegui-Artola et al., 2017), which in turn causes changes in cellular processes such as adhesion, proliferation, and differentiation (Dasgupta \& McCollum, 2019). The completely different response in simulated microgravity conditions on earth demonstrates that the procedure and method of how cells are exposed to a weightless environment are important.

The working principle of the RPM is based on gravity vector nullification, achieved by constantly reorienting samples, such that the gravity vector is distributed in all directions over time (mathematically averaging the gravity vector's trajectory over time to zero) (Wuest et al., 2015). This method implies, however, that simulated microgravity is not reached immediately after switching on the RPM. Mathematical calculations revealed that a gravity value of $0.01 \mathrm{~g}$ can be reached within $30 \mathrm{~min}$. This is, however, a theoretical value, and it is advised to wait for the analysis several hours until biological 
TABLE 1 Gene of interest list for the gene ontology analysis of three functional groups that were highly enriched in SEC compared to RPM: "Adhesion," "Proliferation," and "Differentiation" genes are shown

\begin{tabular}{|c|c|c|}
\hline Gene symbol & Gene name & Gene function \\
\hline ADAM11 & $\begin{array}{l}\text { ADAM metallopeptidase } 11 \text { (disintegrin and } \\
\text { metalloprotease) }\end{array}$ & Cell-cell and cell-matrix adhesion, neurogenesis \\
\hline CAMK1D & Calcium/calmodulin dependent kinase ID & Activates the CREB-dependent gene transcription, involvement in neural plasticity \\
\hline CAMKV & CaM kinase vesicle associated & Calmodulin binding, vesicle associated protein \\
\hline CCL17 & $\mathrm{C}-\mathrm{C}$ motif chemokine ligand 17 & T-cell development, activation of mature T-cells in the thymus \\
\hline COBLL1 & Cordon-Blue protein-like 1 & Actin-network regulation in neurons \\
\hline COL16A1 & Collagen type XVI alpha chain & $\begin{array}{l}\text { Integrin-mediated cell attachment and morphological changes of cellintegrity of } \\
\text { extracellular matrix }\end{array}$ \\
\hline CTSW & Cathepsin W & $\begin{array}{l}\text { Regulation of T-cell activity; upregulated by interleukin-2 (IL-2); associated with the } \\
\text { inner membrane of the ER of NK- and T-cells }\end{array}$ \\
\hline CYB561A3 & Cytochrome b561 family member A3 & Oxireductase, electron transporter; binds $\mathrm{Fe} 3+$ and hemes \\
\hline DAP & Death associated protein & Interferon-gamma mediated cell death, apoptosis, autophagy \\
\hline GRB14 & Growth Factor Receptor bound protein 14 & $\begin{array}{l}\text { Interacts with insulin-stimulated tyrosine kinase signaling cascade, inhibitor of } \\
\text { MAPK3 phosphorylation }\end{array}$ \\
\hline HPCA & Hippocalcin & $\begin{array}{l}\text { Calcium binding protein in regulation of voltage-gated } \mathrm{Ca}^{2+} \text { channels, neuron } \\
\text { specificity }\end{array}$ \\
\hline HPCAL4 & Hippocalcin-like 4 & Same as Hippocalcin; possibly involved in regulation of rhodopsin phosphorylation \\
\hline JAK1/2 & Janus Kinase $1 / 2$ & $\begin{array}{l}\text { Kinase activity in the tyrosine kinase associated signaling cascade; phosphorylates } \\
\text { STATs (involvement in IL-2 mediated inflammation) }\end{array}$ \\
\hline LGALS4 & Galectin 4 & $\begin{array}{l}\text { Binds lactose, assembly of adherence-junctions; involved in myelination, neurite } \\
\text { outgrowth, partially promotes dedifferentiation and proliferation }\end{array}$ \\
\hline LY75 & Lymphocyte antigen 75 & $\begin{array}{l}\text { Reduces proliferation of B-lymphocytesantigen presentation in extracellular space in } \\
\text { sorting compartment according to similarity of antigens }\end{array}$ \\
\hline MOV10 & Mov10 RISC complex RNA helicase & A helicase binding RNA; neural development \\
\hline MUC1 & Mucin 1, cell surface associated & Adhesion of epithelial cells (no neuronal function reported) \\
\hline MYO5B & Myosin VB & Synaptic plasticity, neural shape by transport of organelles along microtubules \\
\hline MYRF & Myelin regulatory factor & Pretranscription factor for oligodendrocyte differentiation and myelination \\
\hline NF1 & Neurofibromin 1 & Influences GTPase activity of Ras (receptor tyrosine kinase signaling) \\
\hline NGEF & $\begin{array}{l}\text { Neuronal guanine nucleotide exchange } \\
\text { factor }\end{array}$ & $\begin{array}{l}\text { Activation of GTPases in the Ras downstream, exchange GDP with GTP (RAC, CDC42 } \\
\text { - > reaction to stress) }\end{array}$ \\
\hline NOTUM & $\begin{array}{l}\text { Notum palmitoleoyl-protein } \\
\text { carboxylesterase }\end{array}$ & $\begin{array}{l}\text { Negative key-regulator of Wnt signaling cascade, serine palmitoleoylation for Wnt } \\
\text { proteins binding to frizzled receptor }\end{array}$ \\
\hline NRIP2 & Nuclear receptor interacting protein 2 & Downregulation of nuclear receptors such as NR1F2 \\
\hline PARP10 & $\begin{array}{l}\text { Poly (ADP-ribose) polymerase family } \\
\text { member } 10\end{array}$ & $\begin{array}{l}\text { Mono-ADP ribosylation of GSK3B resulting in negative effect on GSK3B kinase } \\
\text { activity in Ras downstream }\end{array}$ \\
\hline PDGFA & Platelet derived growth factor subunit $A$ & $\begin{array}{l}\text { PDGFs are involved in neural processes such as cell survival, ion-channel modulation, } \\
\text { neurogenesis, and synaptogenesis; }\end{array}$ \\
\hline PKIB & CAMP-dependent protein kinase inhibitor $\beta$ & $\begin{array}{l}\text { A kinase inhibitor that if overexpressed can lead to several forms of cancer (of } \\
\text { prostate mostly); enriched in the cerebellum }\end{array}$ \\
\hline RHOU & Ras homolog family member $U$ & Member of the Ras downstream signaling, also mediator in Wnt signaling \\
\hline SLC17A7 & Solute carrier family 17 member 17 & Mediates uptake of glutamate into synaptic vesicles \\
\hline SMAD1/5 & SMAD family member 1 & $\begin{array}{l}\text { Downstream mediators of receptor tyrosine kinase signaling; control of neurogenesis; } \\
\text { stimulated by YAP from the Hippo-Pathway }\end{array}$ \\
\hline
\end{tabular}


TABLE 1 (Continued)

\begin{tabular}{|c|c|c|}
\hline Gene symbol & Gene name & Gene function \\
\hline SOS & $\begin{array}{l}\text { SOS Ras/Rac guanine nucleotide exchange } \\
\text { factor }\end{array}$ & Promoting the exchange of GDP with GTP on the GTPase Ras \\
\hline SOX3 & SRY-box 3 & Transcription factor preventing neural development \\
\hline STAT6 & $\begin{array}{l}\text { Signal transducer and activator of } \\
\text { transcription } 6\end{array}$ & $\begin{array}{l}\text { Involved in JAK/STAT signaling cascade induced by for example, IL-2, promoting } \\
\text { inflammation and apoptosis; enhanced expression in ALS }\end{array}$ \\
\hline TMEM176B & Transmembrane protein $176 \mathrm{~B}$ & $\begin{array}{l}\text { Maturation of dendritic cells, development of cerebellar granule cells; contribution to } \\
\mathrm{CD}^{+} \mathrm{T} \text {-cell tumor growth inhibitionlack of TMEM176B leads to enhanced } \\
\text { antitumor activity }\end{array}$ \\
\hline WNT3 & WNT family 3 & $\begin{array}{l}\text { Ligand for frizzled receptor in the Wnt signalling cascade; involved in embryogenesis: } \\
\text { mesoderm and primitive streak formation; regeneration of dorsal root ganglion } \\
\text { cell axons }\end{array}$ \\
\hline ZBTB16 & Zinc finger and BTB domain & $\begin{array}{l}\text { Mediator in poly-ubiquitination by E3- ubiquitin protein ligase; transcriptional } \\
\text { repressor of genes involved in cell-cycle progression }\end{array}$ \\
\hline
\end{tabular}

systems have responded to these altered environmeltal conditions accordingly (Brungs et al., 2016). The lag phase varies substantially and depends heavily on the biological effect of interest. Obviously, fast responding cellular processes adjust to an altered gravitational environment faster than slower occurring and gradually evolving processes. For example, clear differences in the cell cycle of $\mathrm{C} 2 \mathrm{C} 12$ mouse myoblasts were detected after $6 \mathrm{~h}$ of simulated microgravity conditions on the RPM (Benavides Damm et al., 2013). In contrast, scaffold-free formation of multicellular tumor spheroids was investigated after $72 \mathrm{~h}$ of simulated microgravity exposure on the RPM (Warnke et al., 2014).

Shear forces evolving within cell culture flasks attached to the slowmoving platform of the operating RPM is another aspect that needs to be considered when comparing responses of biological systems to the simulated microgravity. The constant reorientation, which is the essence of generating a microgravity-like environment, translates into the cell culture medium. Studies have shown that shear stresses are found along the flask walls, depending on the rotational velocity. The shear stresses in the "bulk volume," however, are much smaller (Wuest et al., 2017). Further experiments are needed to investigate the potentially minimal effect of shear forces in depth.

It is intriguing that BC show substantial alterations to a change in the gravitational environment, and that different cellular responses can be triggered depending on the method used to generate a microgravity environment. These alterations do have the potential to be exploited for particular needs. The actual underlying cellular mechanisms that are forcing the stem cell response in either way, however, need to be explored further by conducting additional experiments.

The Hippo signaling cascade has been associated with cellular response to physical stress exposure (Dasgupta \& McCollum, 2019) and during a space flight, such stress exposure can be experienced. Subsequent to the physical stress exposure Yes-associated protein 1 (YAP1); one key player of the Hippo pathway, translocates into the nucleus and affects the expression of target genes (Aragona et al., 2013; Elosegui-Artola et al., 2017). The adaptation to physical stress entails alterations in the expression of genes involved in proliferation and differentiation (Hansen et al., 2015; Meng et al., 2016).

During hypergravity, cells experience excessive physical stress. In line with current literature, our results indicate an enhanced proliferation rate by upregulation of signaling cascades like the Hippo pathway, WNT, and GPCR signaling (Aragona et al., 2013). The survival and viability of $B C$ in printed scaffolds from space samples were significantly greater than in earth control. In contrast, results from previous studies have shown an increased amount of apoptotic cells in hair follicle-derived neural crest stem cell cultures exposed to simulated microgravity compared to $1 \mathrm{~g}$ conditions (Lin et al., 2016). The improved survival in our experiments may depend on specific features of $B C$ which are not present in hair follicle-derived neural crest stem cells, as we have shown in a previous study where these cells were compared (Kosykh et al., 2015).

Our pathway analyses show activation of several pathways that are strongly associated with proliferation, differentiation, and cell adhesion. Pathways that were strongly altered in our space-flown cells compared to the earth control groups include vascular endothelial growth factor (VEGF)/platelet derived growth factors (PDGF) and calcium signaling. In addition, the expression of genes related to modifications in cell-extracellular interactions was markedly altered. VEGF/PDGF signaling is important for the regulation of stem cell properties. Under normal conditions VEGF/PDGF stimulates proliferation and initial differentiation of rat hippocampal neural stem cells in vitro, inducing markers for neurons and oligodendroglia (Pelegri et al., 2019). VEGF promotes migration and focal adhesion of human neural stem/progenitor cells derived from olfactory epithelium (Ramírez-Rodríguez et al., 2017), and enhances migration of MSCs by regulating focal cell adhesions, thereby promoting MSC neural differentiation potential (Lyu et al., 2013; Wang et al., 2015). 
TAB LE 2 Gene of interest list for the Gene Ontology analysis of three functional groups that were highly enriched in SEC compared to out of the $37^{\circ} \mathrm{CO}_{2}$ incubator: "Adhesion," "Proliferation" and "Differentiation"

\begin{tabular}{|c|c|c|}
\hline Gene symbol & Gene name & Gene function \\
\hline ADAM32 & ADAM metallopeptidase domain 32 & $\begin{array}{l}\text { Member of the disintegrin family of membrane-anchored proteins that may } \\
\text { play a role in brain development }\end{array}$ \\
\hline ANXA2 & Annexin A2 & Calcium binding; may be involved in heat-stress response \\
\hline APOBR & Apolipoprotein B receptor & Cholesterol metabolism; steroid metabolism; lipid transport \\
\hline APOM & Apolipoprotein M & Probably involved in lipid transport \\
\hline ATP8A2 & ATPase phospholipid transporting $8 \mathrm{~A} 2$ & Catalytic component of P4-ATPase flippase; lipid transport \\
\hline CFTR & $\begin{array}{l}\text { Cystic fibrosis transmembrane conductance } \\
\text { regulator }\end{array}$ & Epithelial ion channel \\
\hline $\mathrm{COCH}$ & Cochlin & Plays a role in the control of cell shape and motility \\
\hline CRISPLD2 & $\begin{array}{l}\text { Cysteine rich secretory protein LCCL domain } \\
\text { containing } 2\end{array}$ & Promotes matrix assembly \\
\hline CSMD1 & CUB and Sushi multiple domains 1 & Vesicular protein of unknown function; possibly a tumor suppressor \\
\hline DLK1 & Delta like noncanonical Notch ligand 1 & Possibly a notch ligand; may have a role in neuroendocrine differentiation \\
\hline DND1 & DND microRNA-mediated repression inhibitor 1 & $\begin{array}{l}\text { Prohibits the function of several miRNAs by blocking the accessibility of target } \\
\text { mRNAs }\end{array}$ \\
\hline ECEL1 & Endothelin converting enzyme like 1 & Inactivation of neuronal peptides, metalloprotease \\
\hline GAL3ST1 & Galactose-3-O-sulfotransferase 1 & Lipid metabolism; sphingolipid metabolism \\
\hline GPR101 & G protein-coupled receptor 101 & Orphan G protein-coupled receptor of unknown function \\
\hline GRB10 & Growth factor receptor bound protein 10 & Overexpression results in growth suppression; inhibits tyrosine kinase activity \\
\hline GRIK1 & $\begin{array}{l}\text { Glutamate ionotropic receptor kainate type } \\
\text { subunit } 1\end{array}$ & Ion channel, lipid-gated ion channel, receptor \\
\hline GSTA3 & Glutathione $S$-transferase alpha 3 & Conjugation of reduced glutathione to endogenous hydrophobic electrophiles \\
\hline HHIPL1 & HHIP like 1 & Glucose/sorbosone dehydrogenase family; unknown function \\
\hline HRC & Histidine rich calcium binding protein & May play a role in regulation of calcium \\
\hline IGF2 & Insulin like growth factor 2 & Growth-promoting activity; involved in tissue differentiation \\
\hline $\mathrm{KCNH} 4$ & $\begin{array}{l}\text { Potassium voltage-gated channel subfamily } \mathrm{H} \\
\text { member } 4\end{array}$ & Ion channel, Potassium channel, Voltage-gated channel \\
\hline LAG3 & Lymphocyte activating 3 & Adaptive immunity, immunity \\
\hline MET & MET proto-oncogene, receptor tyrosine kinase & Controlls cell growth \\
\hline MMP19 & Matrix metallopeptidase 19 & Involved in the breakdown of extracellular matrix \\
\hline MYH11 & Myosin heavy chain 11 & Actin-binding, calmodulin-bind, motor protein \\
\hline MYL4 & Myosin light chain 4 & Motor protein, muscle protein \\
\hline OLFML2A & Olfactomedin like $2 \mathrm{~A}$ & $\begin{array}{l}\text { Olfactomedin } 1 \text { contributes top axonal growth, OLFML2A is highly similar to } \\
\text { Olfactomedin } 1 \text {, but has unknown function }\end{array}$ \\
\hline PDE8A & Phosphodiesterase $8 \mathrm{~A}$ & Hydrolyzes the second messenger cAMP \\
\hline PRMT8 & Protein arginine methyltransferase 8 & Arginine methylation as posttranslational modification in e.g. histones \\
\hline SCUBE3 & $\begin{array}{l}\text { Signal peptide, CUB domain and EGF like domain } \\
\text { containing } 3\end{array}$ & Binds to TGFBR2 and activates TGFB signaling \\
\hline SFRP4 & Secreted frizzled related protein 4 & Function as modulator of Wnt \\
\hline SLC10A4 & Solute carrier family 10 member 4 & Transporter for bile acids \\
\hline SLC7A8 & Solute carrier family 7 member 8 & High-affinity transport of neutral amino acids \\
\hline
\end{tabular}


TABLE 2 (Continued)

\begin{tabular}{lll}
\hline Gene symbol & Gene name & Gene function \\
\hline SLITRK3 & SLIT and NTRK like family member 3 & Suppresses neurite outgrowth \\
\hline SNCB & Synuclein $\beta$ & Non-amyloid component of senile plaques \\
\hline SRRM4 & Serine/arginine repetitive matrix 4 & Splicing factor specifically required for neural cell differentiation \\
\hline TGFB1 & Transforming growth factor $\beta 1$ & Growth factor, mitogen \\
\hline TSHR & Thyroid stimulating hormone receptor & TSH binding G protein-coupled receptor \\
\hline TSNAX & Translin associated factor X & Involved in the activation of the RNA-induced silencing complex (RISC) \\
ZWILCH & Zwilch kinetochore protein & Essential component of the mitotic checkpoint, which prevents the cells from \\
\end{tabular}

(a)

$$
\text { Cell proliferation }
$$

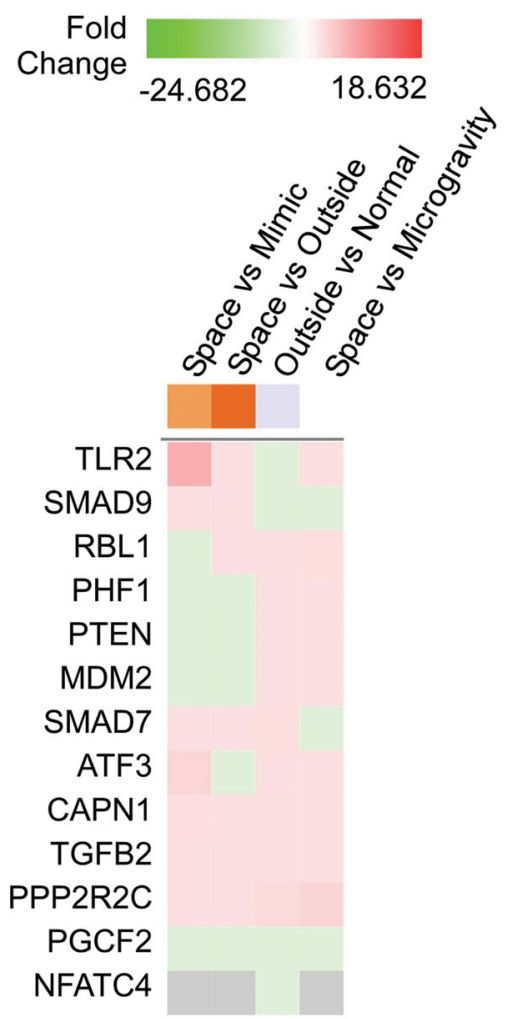

(c)

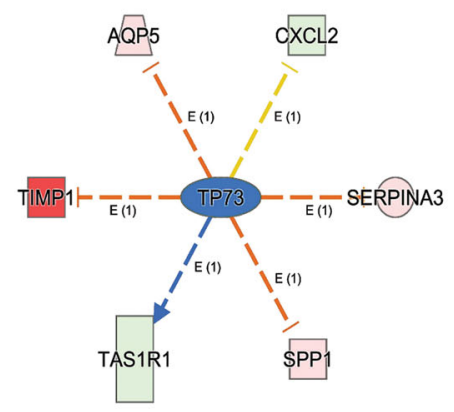

(b)

\section{Cell survival}
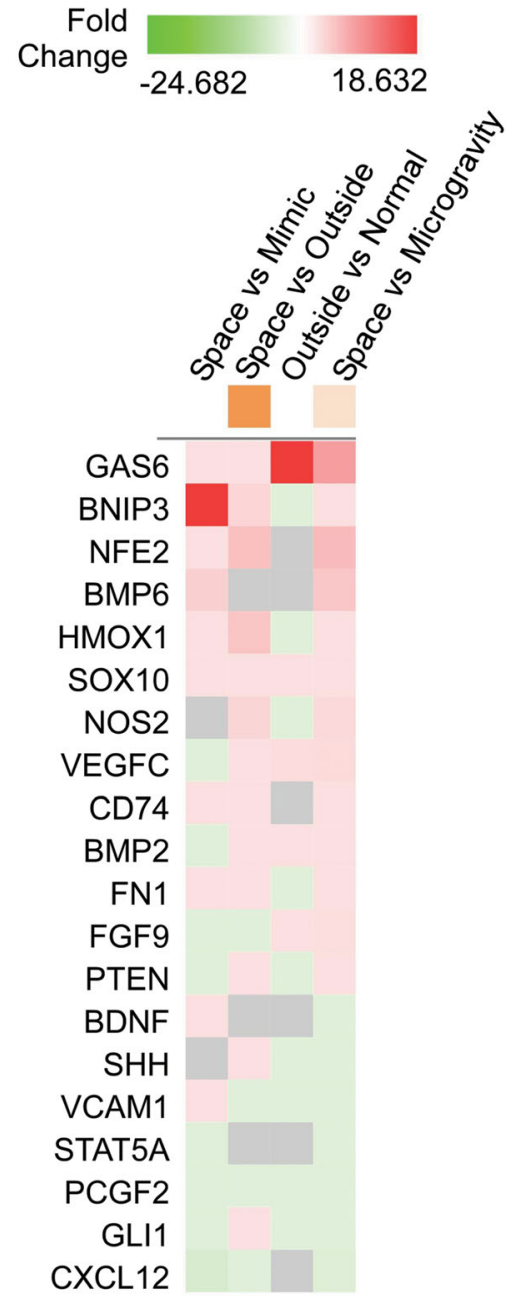

(b) Heatmap displaying genes at least two-fold changed in all individual comparisons between the groups from the cell survival pathway. Here, the summary bar shows that cells exposed to space condition has the highest activation when compared to cells incubated outside the incubator, that is, under similar conditions on earth. (c) TP73 was predicted as a top regulator, with TAS1R showing a strong activation of inhibition

FIGURE 4 Ingenuity pathway analysis (IPA) upregulation or activation, green and blue color tones indicate downregulation or inhibition. White and gray color tones indicate no change. the pathway. (a) Heatmap displaying genes at least two-fold changed in all individual proliferation pathway. Here, the summary bar shows that cells exposed to space condition has incubated outside the incubator, that is, under downregulated or inhibited comparison regarding cell proliferation was outside incubator compared 


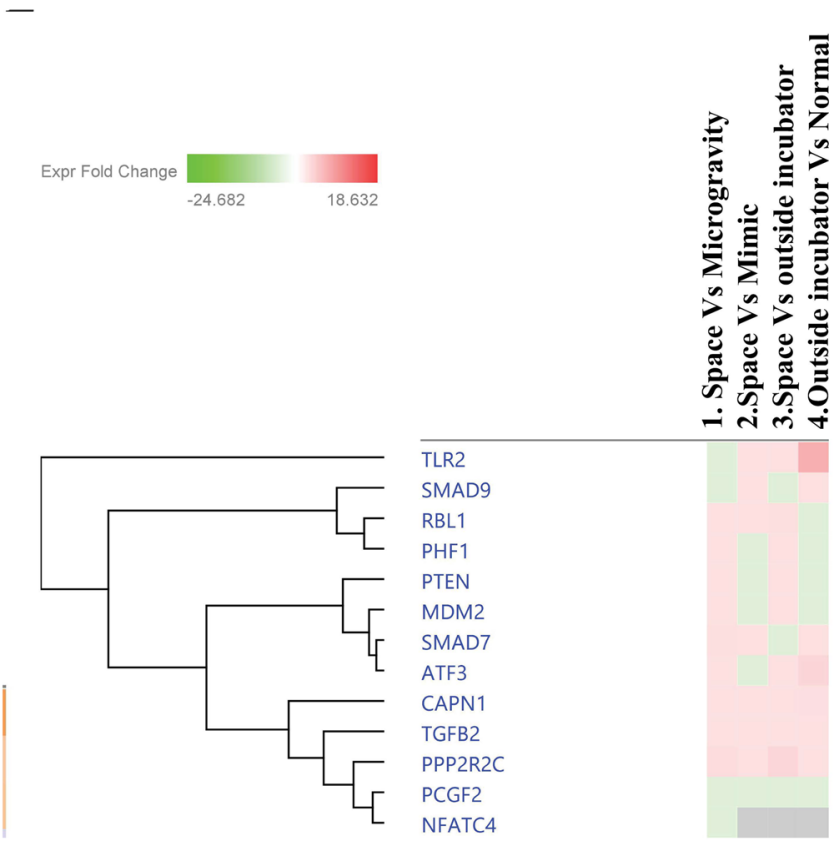

FIGURE 5 Diagram of activated pathways in boundary cap neural crest stem cell (BC), subjected to simulated microgravity or after space flight based on reactome pathway shows the heatmap of genes involved in top senescence pathways in different groups. 1. Space versus microgravity; 2 . Space versus mimic; 3 . Space versus outside incubator; 4. Outside incubator versus normal

Previous studies addressing VEGF expression under conditions of altered gravity generally report downregulation of this growth factor. In simulated microgravity, VEGF was downregulated in a prostate cancer cell line, and adhesion to substrate reduced, while spheroid formation in the medium was enhanced (Hybel et al., 2020).
Simulated microgravity was shown to impair the survival of leukemia cells through a mechanism leading to reduced VEGF signaling (Vincent et al., 2005). Also, space flight as well as in simulated microgravity led to downregulation of VEGFA and VEGFD in a thyroid cancer cell line (Ma et al., 2014). Thus, space flight-induced activation of the VEGF signaling pathway may be a critical step to achieve the improved survival and proliferative capacity of neural stem cells in our experiments and demonstrates a crucial difference between stem cells and cancer cells.

In addition to the activation of the VEGF pathway, we show that the PDGF pathway is also activated. Under normal conditions, PDGF-A induces oligodendroglial progenitor cell (OPC) migration in an ERK-dependent mechanism via regulation of actin reorganization and FAK (Singh et al., 2019). Oligodendrocyte progenitors plated onto a multifunctional film containing PDGF proliferated for at least three days without providing soluble growth factors, while inhibiting the expression of the differentiation marker myelin-basic protein (Moore et al., 2018). In space flight, the PDGF- $\beta$ receptor was downregulated in osteoblasts (Akiyama et al., 1999). Thus, data on the effect of altered gravity conditions on PDGF signaling is extremely limited. Nevertheless, our findings suggest that further analysis of this pathway may be relevant for the regulation of neural stem cell renewal and viability in space conditions.

Calcium signaling pathways were significantly activated in our space flight experiments compared to simulated microgravity controls. $\mathrm{Ca}^{2+}$ signaling is important in many cellular processes in neurons, including long-term potentiation, intercellular communication, synaptic activity, neuroglial interplay. In general, increased $\mathrm{Ca}^{2+}$ is considered beneficial to neuronal activity, providing this increase is moderate and controlled. In recent studies, the number of calbindin immunoreactive neurons in the mouse spinal cord increased after space flight and hindlimb unloading (Porseva et al., 2017; Porseva

TABLE 3 Genes in SEC involved in proliferation and survival

\begin{tabular}{|c|c|c|}
\hline Gene & Function & Expression change \\
\hline TLR2 & Depresses embryonic neural progenitor cell prliferation & Upregulated (1.3 fold) \\
\hline SMAD9 & Inhibits TGF- $\beta$ function to stop cell proliferation, specifically the BMP pathway & Downregulated (1.2 fold) \\
\hline RBL1 & Regulates cell division and acts as a tumor suppressor gene in neurons & Upregulated (3.0 fold) \\
\hline PHF1 & Induces general transcriptional activation by interacting with histones and DNA chromatin methylation & Upregulated (1.7 fold) \\
\hline PTEN & Regulates cell division and acts as a tumor suppressor gene in neurons & Upregulated (2.1 fold) \\
\hline MDM2 & Inhibits p53 to promote cell division & Upregulated (2.3 fold) \\
\hline SMAD7 & Inhibits general TGF- $\beta$ function to stop cell proliferation & Downregulated (1.4 fold) \\
\hline ATF3 & General transcriptional activator, cAMP dependent & Upregulated (1.1 fold) \\
\hline CAPN1 & Suppresses lysosomal function and auto phagosome formation, to promote cell survival. & Upregulated (1.6 fold) \\
\hline TGFB2 & A growth factor and mitogen. Important for development of various cell types & Upregulated (2.6 fold) \\
\hline PPP2R2C & $\begin{array}{l}\text { Suppresses the mTOR to promote cell survival. Function as a tumor suppressor gene to inhibit cell } \\
\text { proliferation. }\end{array}$ & Upregulated (3.7 fold) \\
\hline PCGF2 & $\begin{array}{l}\text { Transcriptional repressor and function as a tumor suppressor. Important for differentiation of specific cell } \\
\text { types }\end{array}$ & Downregulated (1.4 fold) \\
\hline
\end{tabular}


et al., 2018), whereas labeling for calretinin decreased following hindlimb unloading (Porseva et al., 2018).

Previous studies have shown that cells exposed to gravity alterations modify their interaction with the extracellular environment (Ebnerasuly et al., 2018; Lin et al., 2020). Our gene analyses show that processes involving integrin and collagen synthesis are differently regulated, changes that are in line with what can be expected under the physical stress during space flight.

Relatively few studies that directly compared the effects of space flight with ground-based mimicking experiments have been carried out so far. Previous results mostly indicate that morphological and molecular changes following simulated microgravity and space flight are similar, although often with quantitative differences in the direction of the alterations (Camberos et al., 2019; Stamenković et al., 2010; Talbot et al., 2010; Wuest et al., 2015). However, extensive analysis of gene activation in a thyroid cancer cell line subjected to microgravity in space as well as simulated microgravity, revealed differences in activated pathways under these two experimental conditions (Ma et al., 2014).

Studies on cardiac progenitor cells (Baio et al., 2018), and hematopoietic stem/progenitor cells have also demonstrated distinct differences in activated pathways (Wang et al., 2019). Furthermore, separate studies, using the same cell type and comparable experimental setups, suggest opposite directions between space flight and simulated microgravity with regard to changes in the expression of adhesion molecules (reviewed in Lin et al., 2020). Space flown BC displayed a markedly increased proliferation rate, and at the same time improved viability compared to cells exposed to simulated microgravity. These observations are in line with a previous demonstration that human mesenchymal stem cells (hMSCs) cultured under $10^{3} \mathrm{~g}$ show a significantly increased proliferation rate compared to hMSCs in $1 g$ (Yuge et al., 2006). Along a similar line, adipose-derived stem cells were shown to proliferate at a higher rate when subjected to hypergravity than $1 g$ conditions (Tavakolinejad et al., 2015).

An important aspect for the comparison of our results with those of the existing literature is the temporal dimension. In previous studies, cells were kept in space and thus exposed to microgravity for days or weeks, allowing them to gradually adapt to the microgravity conditions. With the short duration of space flight in our experiments, the period for restoring cellular homeostasis would take place entirely after the return of BC to $1 \mathrm{~g}$ conditions on earth. Still, the novel properties of BC after the flight were maintained for several months, rather than returning to pre-flight condition.

Taken together, we demonstrate that $\mathrm{BC}$ subjected to only $12 \mathrm{~min}$ sounding rocket altered gravity conditions acquired new features compared to all earth controls. In particular, space flown cells show not only extreme resilience to space flight conditions but actually seem to acquire a long-lasting capacity for cell renewal, a property of benefit for the cells themselves, and of potential relevance for translational research and applications. The long-term maintenance of this property indicates that short space flight induces epigenetic changes that influence proliferation, in stem cells. Further experiments will contribute to our understanding of mechanisms for long term maintenance of novel stem cell properties after space flight that may be attractive for exploitation in regenerative medicine.

\section{5 | LIMITATIONS OF THE STUDY}

When performing this study, we had to make some priorities in terms of analytical options, to obtain sufficient material for the prime outcome assessment of the experiments, that is, reproducible analysis of gene expression in SEC, and control groups. Due to this objective, we were not able to perform counts of cultured cells, including their rate of proliferation, before collecting them for the gene analysis, as our main task at that stage was to generate as much progeny as possible for the followup analyses. However, we were able to make some estimates on the renewal capacity among cells subjected to different experiments. Thus, from every single well in the culture chamber with SEC, we retrieved 24 new wells, whereas we only obtained 2-4 wells from culture chambers with ground control cells. These observations strongly indicate a remarkable rate of $\mathrm{BC}$ renewal in SEC compared to ground controls.

\section{ACKNOWLEDGMENTS}

Elena N. Kozlovaw is supported by the Swedish National Space Agency. Robert Fredriksson is supported by the Swedish Research Council, Åhlens foundation, Gunvor and Josef Anérs foundation, and the Swedish Foundation for Strategic Research.

\section{CONFLICT OF INTERESTS}

The authors declare that there are no conflict of interests.

\section{AUTHOR CONTRIBUTIONS}

Conceptualization: Elena N. Kozlova, Christian Lockowandt, Robert Fredriksson. Writing-original draft: Elena N. Kozlova, Robert Fredriksson, Marcel Egli. Writing-review and editing: Yilin Han, Lukas Zeger, Rekha Tripathi, Marcel Egli, Fabian Ille, Christian Lockowandt, Gunnar Florin, Itedale N. Redwan, Robert Fredriksson, Elena N. Kozlova. Cell culture and analysis: Yilin Han. Bioprinting: E. Atic and Itedale N. Redwan. Gen expression analysis: Lukas Zeger, Rekha Tripathi, Elena N. Kozlova, Robert Fredriksson. Preflight tests and postflight RPM experiments: Christian Lockowandt, Gunnar Florin, Marcel Egli, Fabian Ille. Bioinformatics: Rekha Tripathi, Robert Fredriksson, Lukas Zeger. Supervision: Elena N. Kozlova. All authors have read and approved the manuscript and participated in the interpretation of the results.

\section{DATA AVAILABILITY STATEMENT}

The original contributions presented in the study are included in the article. Further inquiries can be directed to the corresponding author.

\section{REFERENCES}

Acharya, A., Brungs, S., Henry, M., Rotshteyn, T., Singh Yaduvanshi, N., Wegener, L., Jentzsch, S., Hescheler, J., Hemmersbach, R., Boeuf, H., \& Sachinidis, A. (2018). Modulation of differentiation processes in murine 
embryonic stem cells exposed to parabolic flight-induced acute hypergravity and microgravity. Stem Cells and Development, 27(12), 838-847. https://doi.org/10.1089/scd.2017.0294

Aggarwal, T., Hoeber, J., Ivert, P., Vasylovska, S., \& Kozlova, E. N. (2017). Boundary cap neural crest stem cells promote survival of mutant SOD1 motor neurons. Neurotherapeutics, 14(3), 773-783. https:// doi.org/10.1007/s13311-016-0505-8

Akiyama, H., Kanai, S., Hirano, M., Shimokawa, H., Katano, H., Mukai, C., Nagaoka, S., Morita, S., \& Kumei, Y. (1999). Expression of PDGF-beta receptor, EGF receptor, and receptor adaptor protein Shc in rat osteoblasts during spaceflight. Molecular and Cellular Biochemistry, 202(1-2), 63-71. https://doi.org/10.1023/a:1007097511914

Aldskogius, H., Berens, C., Kanaykina, N., Liakhovitskaia, A., Medvinsky, A., Sandelin, M., Schreiner, S., Wegner, M., HjerlingLeffler, J., \& Kozlova, E. N. (2009). Regulation of boundary cap neural crest stem cell differentiation after transplantation. Stem Cells, 27(7), 1592-1603. https://doi.org/10.1002/stem.77

Aquino, J. B., Hjerling-Leffler, J., Koltzenburg, M., Edlund, T., Villar, M. J., \& Ernfors, P. (2006). In vitro and in vivo differentiation of boundary cap neural crest stem cells into mature Schwann cells. Experimental Neurology, 198(2), 438-449. https://doi.org/10.1016/j.expneurol. 2005.12.015

Aragona, M., Panciera, T., Manfrin, A., Giulitti, S., Michielin, F., Elvassore, N., Dupont, S., \& Piccolo, S. (2013). A mechanical checkpoint controls multicellular growth through YAP/TAZ regulation by actin-processing factors. Cell, 154(5), 1047-1059. https://doi.org/10.1016/j.cell.2013.07.042

Baio, J., Martinez, A. F., Bailey, L., Hasaniya, N., Pecaut, M. J., \& KearnsJonker, M. (2018). Spaceflight activates protein kinase C alpha signaling and modifies the developmental stage of human neonatal cardiovascular progenitor cells. Stem Cells and Development, 27(12), 805-818. https://doi.org/10.1089/scd.2017.0263

Benavides Damm, T., Richard, S., Tanner, S., Wyss, F., Egli, M., \& FrancoObregón, A. (2013). Calcium-dependent deceleration of the cell cycle in muscle cells by simulated microgravity. FASEB Journal, 27(5), 2045-2054. https://doi.org/10.1096/fj.12-218693

Blaber, E. A., Finkelstein, H., Dvorochkin, N., Sato, K. Y., Yousuf, R., Burns, B. P., Globus, R. K., \& Almeida, E. A. (2015). Microgravity reduces the differentiation and regenerative potential of embryonic stem cells. Stem Cells and Development, 24(22), 2605-2621. https:// doi.org/10.1089/scd.2015.0218

Brungs, S., Egli, M., Wuest, S. I., Christianen, P. C. M., van Loon, J., NgoAnh, T. J., \& Hemmersbach, R. (2016). Facilities for simulation of microgravity in the ESA ground-based facilit programme. Microgravity Science and Technology, 28(3), 191-203. https://doi. org/10.1007/s12217-015-9471-8

Camberos, V., Baio, J., Bailey, L., Hasaniya, N., Lopez, L. V., \& KearnsJonker, M. (2019). Effects of spaceflight and simulated microgravity on YAP1 expression in cardiovascular progenitors: Implications for cell-based repair. International Journal of Molecular Sciences, 20(11), 2742. https://doi.org/10.3390/ijms20112742

Cao, D., Song, J., Ling, S., Niu, S., Lu, L., Cui, Z., Li, Y., Hao, S., Zhong, G., Qi, Z., Sun, W., Yuan, X., Li, H., Zhao, D., Jin, X., Liu, C., Wu, X., Kan, G., Cao, H., ... Li, Y. (2019). Hematopoietic stem cells and lineage cells undergo dynamic alterations under microgravity and recovery conditions. FASEB Journal, 33(6), 6904-6918. https://doi. org/10.1096/fj.201802421RR

Chen, J., Liu, R., Yang, Y., Li, J., Zhang, X., Li, J., Wang, Z., \& Ma, J. (2011). The simulated microgravity enhances the differentiation of mesenchymal stem cells into neurons. Neuroscience Letters, 505(2), 171-175. https://doi.org/10.1016/j.neulet.2011.10.014

Chen, Z., Luo, Q., Lin, C., Kuang, D., \& Song, G. (2016). Simulated microgravity inhibits osteogenic differentiation of mesenchymal stem cells via depolymerizing F-actin to impede TAZ nuclear translocation. Scientific Reports, 6, 30322. https://doi.org/10.1038/srep30322
Chen, Z., Luo, Q., Lin, C., \& Song, G. (2015). Simulated microgravity inhibits osteogenic differentiation of mesenchymal stem cells through down regulating the transcriptional co-activator TAZ. Biochemical and Biophysical Research Communications, 468(1-2), 21-26. https://doi.org/10.1016/j.bbrc.2015.11.006

Dasgupta, I., \& McCollum, D. (2019). Control of cellular responses to mechanical cues through YAP/TAZ regulation. Journal of Biological Chemistry, 294(46), 17693-17706. https://doi.org/10.1074/jbc. REV119.007963

Demontis, G. C., Germani, M. M., Caiani, E. G., Barravecchia, I., Passino, C., $\&$ Angeloni, D. (2017). Human pathophysiological adaptations to the space environment. Frontiers in Physiology, 8, 547. https://doi.org/10. 3389/fphys.2017.00547

Ebnerasuly, F., Hajebrahimi, Z., Tabaie, S. M., \& Darbouy, M. (2018), Simulated microgravity condition alters the gene expression of some ECM and adhesion molecules in adipose derived stem cells. International Journal of Molecular and Cellular Medicine, 7(3), 146-157.

Elosegui-Artola, A., Andreu, I., Beedle, A. E. M., Lezamiz, A., Uroz, M., Kosmalska, A. J., Oria, R., Kechagia, J. Z., Rico-Lastres, P., Le Roux, A. L., Shanahan, C. M., Trepat, X., Navajas, D., GarciaManyes, S., Roca-Cusachs, P., \& Force Triggers, Y. A. P. (2017). Nuclear entry by regulating transport across nuclear pores. Cell, 171(6), 1397-1410e14. https://doi.org/10.1016/j.cell.2017.10.008

Espinosa-Jeffrey, A., Paez, P. M., Cheli, V. T., Spreuer, V., Wanner, I., \& de Vellis, J. (2013). Impact of simulated microgravity on oligodendrocyte development: Implications for central nervous system repair. PLOS One, 8(12), e76963. https://doi.org/10.1371/ journal.pone.0076963

Fabregat, A., Korninger, F., Viteri, G., Sidiropoulos, K., Marin-Garcia, P., Ping, P., Wu, G., Stein, L., D'Eustachio, P., \& Hermjakob, H. (2018). Reactome graph database: Efficient access to complex pathway data. PLOS Computational Biology, 14(1), e1005968. https://doi.org/ 10.1371/journal.pcbi.1005968. eCollection 2018 Jan

Grapensparr, L., Vasylovska, S., Li, Z., Olerud, J., Jansson, L., Kozlova, E., \& Carlsson, P. O. (2015). Co-transplantation of human pancreatic islets with post-migratory neural crest stem cells increases $\beta$-cell proliferation and vascular and neural regrowth. Journal of Clinical Endocrinology and Metabolism, 100(4), E583-E590. https://doi.org/ 10.1210/jc.2014-4070

Graziano, A. C. E., Avola, R., Perciavalle, V., Nicoletti, F., Cicala, G., Coco, M., \& Cardile, V. (2018). Physiologically based microenvironment for in vitro neural differentiation of adiposederived stem cells. World Journal of Stem Cells, 10(3), 23-33. https:// doi.org/10.4252/wjsc.v10.i3.23

Grimm, D., Egli, M., Krüger, M., Riwaldt, S., Corydon, T. J., Kopp, S., Wehland, M., Wise, P., Infanger, M., Mann, V., \& Sundaresan, A. (2018). Tissue engineering under microgravity conditions-use of stem cells and specialized cells. Stem Cells and Development, 27(12), 787-804. https://doi.org/10.1089/scd.2017.0242

Grimm, D., Wehland, M., Corydon, T. J., Richter, P., Prasad, B., Bauer, J., Egli, M., Kopp, S., Lebert, M., \& Krüger, M. (2020). The effects of microgravity on differentiation and cell growth in stem cells and cancer stem cells. Stem Cells Translational Medicine, 9(8), 882-894. https://doi.org/10.1002/sctm.20-0084

Grouwels, G., Vasylovska, S., Olerud, J., Leuckx, G., Ngamjariyawat, A., Yuchi, Y., Jansson, L., Van de Casteele, M., Kozlova, E. N., \& Heimberg, H. (2012). Differentiating neural crest stem cells induce proliferation of cultured rodent islet beta cells. Diabetologia, 55(7), 2016-2025. https://doi.org/10.1007/s00125-012-2542-0

Hansen, C. G., Moroishi, T., \& Guan, K. L. (2015). YAP and TAZ: A nexus for Hippo signaling and beyond. Trends in Cell Biology, 25(9), 499-513. https://doi.org/10.1016/j.tcb.2015.05.002

Hatzistergos, K. E., Jiang, Z., Valasaki, K., Takeuchi, L. M., Balkan, W., Atluri, P., Saur, D., Seidler, B., Tsinoremas, N., DiFede, D. L., \& 
Hare, J. M. (2018). Simulated microgravity impairs cardiac autonomic neurogenesis from neural crest cells. Stem Cells and Development, 27(12), 819-830. https://doi.org/10.1089/scd. 2017.0265

Hjerling-Leffler, J., Marmigère, F., Heglind, M., Cederberg, A., Koltzenburg, M., Enerbäck, S., \& Ernfors, P. (2005). The boundary cap: A source of neural crest stem cells that generate multiple sensory neuron subtypes. Development, 132(11), 2623-2632. https://doi.org/10.1242/dev.01852

Huang da, W., Sherman, B. T., \& Lempicki, R. A. (2009). Bioinformatics enrichment tools: Paths toward the comprehensive functional analysis of large gene lists. Nucleic Acids Research, 37(1), 1-13. https://doi.org/10.1093/nar/gkn923 Epub 2008 No v 25

Huang da, W., Sherman, B. T., Stephens, R., Baseler, M. W., Lane, H. C., \& Lempicki, R. A. (2008). DAVID gene ID conversion tool. Bioinformation, 2(10), 428-430. https://doi.org/10.6026/ 97320630002428

Hybel, T. E., Dietrichs, D., Sahana, J., Corydon, T. J., Nassef, M. Z., Wehland, M., Krüger, M., Magnusson, N. E., Bauer, J., Utpatel, K., Infanger, M., Grimm, D., \& Kopp, S. (2020). Simulated microgravity influences VEGF, MAPK, and PAM signaling in prostate cancer cells. International Journal of Molecular Sciences, 21(4), 1263. https://doi. org/10.3390/ijms21041263

Imura, T., Nakagawa, K., Kawahara, Y., \& Yuge, L. (2018). Stem cell culture in microgravityand its application in cell-based therapy. Stem Cells and Development, 27(18), 1298-1302. https://doi.org/10.1089/scd. 2017.0298

Jassal, B., Matthews, L., Viteri, G., Gong, C., Lorente, P., Fabregat, A., Sidiropoulos, K., Cook, J., Gillespie, M., Haw, R., Loney, F., May, B., Milacic, M., Rothfels, K., Sevilla, C., Shamovsky, V., Shorser, S., Varusai, T., Weiser, J., ... D'Eustachio, P. (2020). The reactome pathway knowledgebase. Nucleic Acids Research, 48(D1), D498-D503. https://doi.org/10.1093/nar/gkz1031

Kosykh, A., Ngamjariyawat, A., Vasylovska, S., Konig, N., Trolle, C., Lau, J., Mikaelyan, A., Panchenko, M., Carlsson, P. O., Vorotelyak, E., \& Kozlova, E. N. (2015). Neural crest stem cells from hair follicles and boundary cap have different effects on pancreatic islets in vitro. International Journal of Neuroscience, 125(7), 547-554. https://doi. org/10.3109/00207454.2014.950373

Lau, J., Vasylovska, S., Kozlova, E. N., \& Carlsson, P. O. (2015). Surface coating of pancreatic islets with neural crest stem cells improves engraftment and function after intraportal transplantation. Cell Transplantation, 24(11), 2263-2272. https://doi.org/10.3727/ $096368915 \times 686184$

Leyton-Jaimes, M., Ivert, P., Hoeber, J., Han, Y., Feiler, A., Zhou, C., Pankratova, S., Shoshan-Barmatz, V., Israelson, A., \& Kozlova, E. N. (2020). Empty mesoporous silica particles significantly delay disease progression and extend survival in a mouse model of ALS. Scientific Reports, 10, 20675. https://doi.org/10.1038/s41598-020-77578-x

Li, H., Zhu, H., Zhang, F., Dong, X., Hao, T., Jiang, X., Zheng, W., Zhang, T., Chen, X., Wang, P., Na, J., Wang, C., \& Zhou, J. (2019). Spaceflight promoted myocardial differentiation of induced pluripotent stem cells: Results from Tianzhou-1 space mission. Stem Cells and Development, 28(6), 357-360. https://doi.org/10.1089/scd. 2018.0240

Lin, S. C., Gou, G. H., Hsia, C. W., Ho, C. W., Huang, K. L., Wu, Y. F., Lee, S. Y., \& Chen, Y. H. (2016). Simulated microgravity disrupts cytoskeleton organization and increases apoptosis of rat neural crest stem cells via upregulating CXCR4 expression and RhoAROCK1-p38 MAPK-p53 signaling. Stem Cells and Development, 25(15), 1172-1193.

Lin, X., Zhang, K., Wei, D., Tian, Y., Gao, Y., Chen, Z., \& Qian, A. (2020). The impact of spaceflight and simulated microgravity on cell adhesion. International Journal of Molecular Sciences, 21(9), 3031.
Lyu, J., Hu, Y., Xu, X., \& Zhang, H. (2013). Dynamics of focal adhesions and reorganization of F-actin in VEGF-stimulated NSCs under varying differentiation states. Journal of Cellular Biochemistry, 114(8), 1744-1759. https://doi.org/10.1002/jcb.24517

Ma, X., Pietsch, J., Wehland, M., Schulz, H., Saar, K., Hübner, N., Bauer, J., Braun, M., Schwarzwälder, A., Segerer, J., Birlem, M., Horn, A., Hemmersbach, R., Waßer, K., Grosse, J., Infanger, M., \& Grimm, D. (2014). Differential gene expression profile and altered cytokine secretion of thyroid cancer cells in space. FASEB Journal, 28(2), 813-835. https://doi.org/10.1096/fj.13-243287

Mao, X., Chen, Z., Luo, Q., Zhang, B., \& Song, G. (2016). Simulated microgravity inhibits the migration of mesenchymal stem cells by remodeling actin cytoskeleton and increasing cell stiffness. Cytotechnology, 68(6), 2235-2243. https://doi.org/10.1007/ s10616-016-0007-x

Maro, G. S., Vermeren, M., Voiculescu, O., Melton, L., Cohen, J., Charnay, P., \& Topilko, P. (2004). Neural crest boundary cap cells constitute a source of neuronal and glial cells of the PNS. Nature Neuroscience, 7(9), 930-938. https://doi.org/10.1038/nn1299

Meng, Z., Moroishi, T., \& Guan, K. L. (2016). Mechanisms of Hippo pathway regulation. Genes and Development, 30(1), 1-17. https://doi. org/10.1101/gad.274027.115

Moore, L., Skop, N. B., Rothbard, D. E., Corrubia, L. R., \& Levison, S. W. (2018). Tethered growth factors on biocompatible scaffolds improve stemness of cultured rat and human neural stem cells and growth of oligodendrocyte progenitors. Methods, 133, 54-64. https://doi.org/ 10.1016/j.ymeth.2017.08.015

Ngamjariyawat, A., Turpaev, K., Welsh, N., \& Kozlova, E. N. (2012). Coculture of insulin-producing RIN5AH cells with neural crest stem cells protects partially against cytokine-induced cell death. Pancreas, 41(3), 490-492. https://doi.org/10.1097/MPA.0b013e31823fcfa

Olerud, J., Kanaykina, N., Vasylovska, S., King, D., Sandberg, M., Jansson, L., \& Kozlova, E. N. (2009). Neural crest stem cells increase beta cell proliferation and improve isletfunction in co-transplanted murine pancreatic islets. Diabetologia, 52(12), 2594-2601. https:// doi.org/10.1007/s00125-009-1544-z. Erratum in: Diabetologia. 2010 Feb;53(2):396. Vasilovska, S [corrected to Vasylovska, S].

Ozcivici, E., Luu, Y. K., Rubin, C. T., \& Judex, S. (2010). Low-level vibrations retain bone marrow's osteogenic potential and augment recovery of trabecular bone during reambulation. PLOS One, 5(6), e11178. https://doi.org/10.1371/journal.pone.0011178

Pelegri, N. G., Gorrie, C. A., \& Santos, J. (2019). Rat hippocampal neural stem cell modulation using PDGF, VEGF, PDGF/VEGF, and BDNF. Stem Cells International, 2019, 4978917. https://doi.org/10.1155/ 2019/4978917

Porseva, V. V., Emanuilov, A. I., \& Masliukov, P. M. (2018). Changes in the expression of calbindin and calretinin in interneurons of the spinal dorsal horns under conditions of antiorthostatic suspension in mice. Bulletin of Experimental Biology and Medicine, 166(1), 22-25.

Porseva, V. V., Shilkin, V. V., Strelkov, A. A., Krasnov, I. B., \& Masliukov, P. M. (2017). Changes in the neurochemical composition of motor neurons of the spinal cord in mice under conditions of space flight. Bulletin of Experimental Biology and Medicine, 162(3), 336-339.

Radomska, K. J., \& Topilko, P. (2017). Boundary cap cells in development and disease. Current Opinion in Neurobiology, 47, 209-215. https:// doi.org/10.1016/j.conb.2017.11.003

Ramírez-Rodríguez, G. B., Perera-Murcia, G. R., Ortiz-López, L., VegaRivera, N. M., Babu, H., García-Anaya, M., \& González-Olvera, J. J. (2017). Vascular endothelial growth factor influences migration and focal adhesions, but not proliferation or viability, of human neural stem/progenitor cells derived from olfactory epithelium. Neurochemistry International, 108, 417-425. https://doi.org/10. 1016/j.neuint.2017.06.001 
Schizas, N., König, N., Andersson, B., Vasylovska, S., Hoeber, J., Kozlova, E. N., \& Hailer, N. P. (2018). Neural crest stem cells protect spinal cord neurons from excitotoxic damageand inhibit glial activation by secretion of brain-derived neurotrophic factor. Cell and Tissue Research, 372(3), 493-505. https://doi.org/10.1007/ s00441-018-2808-z

Shinde, V., Brungs, S., Henry, M., Wegener, L., Nemade, H., Rotshteyn, T., Acharya, A., Baumstark-Khan, C., Hellweg, C. E., Hescheler, J., Hemmersbach, R., \& Sachinidis, A. (2016). Simulated microgravity modulates differentiation processes of embryonic stem cells. Cellular Physiology and Biochemistry, 38(4), 1483-1499. https://doi.org/10. 1159/000443090

Singh, J., Sharma, K., Frost, E. E., \& Pillai, P. P. (2019). Role of PDGF-Aactivated ERK signaling mediated FAK-paxillin interaction in oligodendrocyte progenitor cell migration. Journal of Molecular Neuroscience, 67(4), 564-573. https://doi.org/10.1007/s12031019-1260-1

Stamenković, V., Keller, G., Nesic, D., Cogoli, A., \& Grogan, S. P. (2010). Neocartilage formation in $1 \mathrm{~g}$, simulated, and microgravity environments: Implications for tissue engineering. Tissue Engineering. Part A, 16(5), 1729-1736. https://doi.org/10.1089/ten. tea.2008.0624

Talbot, N. C., Caperna, T. J., Blomberg, L., Graninger, P. G., \& Stodieck, L. S. (2010). The effects of space flight and microgravity on the growth and differentiation of PICM-19 pig liver stem cells. In Vitro Cellular \& Developmental Biology-Animal, 46(6), 502-515. https://doi.org/10. 1007/s11626-010-9302-6

Tavakolinejad, A., Rabbani, M., \& Janmaleki, M. (2015). Effects of hypergravity on adipose-derived stem cell morphology, mechanical property and proliferation. Biochemical and Biophysical Research Communications, 464(2), 473-479. https://doi.org/10.1016/j.bbrc. 2015.06.160

Trolle, C., Konig, N., Abrahamsson, N., Vasylovska, S., \& Kozlova, E. N. (2014). Boundary cap neural crest stem cells homotopically implanted to the injured dorsal root transitional zone give rise to different types of neurons and glia in adult rodents. BMC Neuroscience, 15, 60. https://doi.org/10.1186/1471-2202-15-60

Vincent, L., Avancena, P., Cheng, J., Rafii, S., \& Rabbany, S. Y. (2005). Simulated microgravity impairs leukemic cell survival through altering VEGFR-2/VEGF-A signaling pathway. Annals of Biomedical Engineering, 33(10), 1405-1410.

Vi, ntersten, K., Monetti, C., Gertsenstein, M., Zhang, P., Laszlo, L., Biechele, S., Nagy, \& A. (2004). Mouse in red: Red fluorescent protein expression in mouse ES cells, embryos, and adult animals. Genesis, 40(4), 241-246. https://doi.org/10.1002/gene.20095, erratum in Genesis. 2005 Jul;42(3):218.

Wang, H., Wang, X., Qu, J., Yue, Q., Hu, Y., \& Zhang, H. (2015). VEGF enhances the migration of MSCs in neural differentiation by regulating focal adhesion turnover. Journal of Cellular Physiology, 230(11), 2728-2742. https://doi.org/10.1002/jcp.24997

Wang, P., Tian, H., Zhang, J., Qian, J., Li, L., Shi, L., \& Zhao, Y. (2019). Spaceflight/microgravity inhibits the proliferation of hematopoietic stem cells by decreasing Kit-Ras/cAMP-CREB pathway networks as evidenced by RNA-Seq assays. FASEB Journal, 33(5), 5903-5913. https://doi.org/10.1096/fj.201802413R

Warnke, E., Pietsch, J., Wehland, M., Bauer, J., Infanger, M., Görög, M., Hemmersbach, R., Braun, M., Ma, X., Sahana, J., \& Grimm, D. (2014). Spheroid formation of human thyroid cancer cells under simulated microgravity: A possible role of CTGF and CAV1. Cell Communication and Signaling, 12, 32. https://doi.org/10.1186/1478-811X-12-32

Wuest, S. L., Richard, S., Kopp, S., Grimm, D., \& Egli, M. (2015). Simulated microgravity: Critical review on the use of random positioning machines for mammalian cell culture. BioMed Research International, 2015, 971474. https://doi.org/10.1155/ 2015/971474

Wuest, S. L., Richard, S., Walther, I., Furrer, R., Anderegg, R., Sekler, J., \& Egli, M. (2014). A novel microgravity simulator applicable for threedimensional cell culturing. Microgravity Science and Technology, 26 1-12.

Wuest, S. L., Stern, P., Casartelli, E., \& Egli, M. (2017). Fluid dynamics appearing during simulated microgravity using random positioning machines. PLOS One, 12(1), e0170826. https://doi.org/10.1371/ journal.pone.0170826

Yuge, L., Kajiume, T., Tahara, H., Kawahara, Y., Umeda, C., Yoshimoto, R., Wu, S. L., Yamaoka, K., Asashima, M., Kataoka, K., \& Ide, T. (2006). Microgravity potentiates stem cell proliferation while sustaining the capability of differentiation. Stem Cells and Development, 15(6), 921-929.

Yuge, L., Sasaki, A., Kawahara, Y., Wu, S. L., Matsumoto, M., Manabe, T., Kajiume, T., Takeda, M., Magaki, T., Takahashi, T., Kurisu, K., \& Matsumoto, M. (2011). Simulated microgravity maintains the undifferentiated state and enhances the neural repair potential of bone marrow stromal cells. Stem Cells and Development, 20(5), 893-900. https://doi.org/10.1089/scd.2010.0294

Zarrinpour, V., Hajebrahimi, Z., \& Jafarinia, M. (2017). Expression pattern of neurotrophins and their receptors during neuronal differentiation of adipose-derived stem cells in simulated microgravity condition. Iranian Journal of Basic Medical Sciences, 20(2), 178-186. https://doi. org/10.22038/ijbms.2017.8244

Zhang, C., Li, L., Chen, J., \& Wang, J. (2015). Behavior of stem cells under outer-space microgravity and ground-based microgravity simulation. Cell Biology International, 39(6), 647-656. https://doi. org/10.1002/cbin.10452

Zujovic, V., Thibaud, J., Bachelin, C., Vidal, M., Coulpier, F., Charnay, P., Topilko, P., \& Baron-Van Evercooren, A. (2010). Boundary cap cells are highly competitive for CNS remyelination: Fast migration and efficient differentiation in PNS and CNS myelin-forming cells. Stem Cells, 28(3), 470-479. https://doi.org/10.1002/stem.290

Zujovic, V., Thibaud, J., Bachelin, C., Vidal, M., Deboux, C., Coulpier, F., Stadler, N., Charnay, P., Topilko, P., Baron-Van, \& Evercooren, A. (2011). Boundary cap cells are peripheral nervous system stem cells that can be redirected into central nervous system lineages. Proceedings of the National Academy of Sciences of the United States of America, 108(26), 10714-10719. https://doi.org/10.1073/pnas. 1018687108

How to cite this article: Han, Y., Zeger, L., Tripathi, R., Egli, M., Ille, F., Lockowandt, C., Florin, G., Atic, E., Redwan, I. N., Fredriksson, R., \& Kozlova, E. N. (2021). Molecular genetic analysis of neural stem cells after space flight and simulated microgravity on earth. Biotechnology and Bioengineering, 118, 3832-3846. https://doi.org/10.1002/bit.27858 